\title{
Rapid Detection of Carbapenemase Detection by VITEK-MS
}

\section{öz}

Son yıllarda karbapenemaz üreten Enterobacteriaceae kaynaklı enfeksiyonların dünya çapında artması önemli halk sağlığı sorunudur. Araştırıcılar, mikroorganizmanın kısa sürede tanımlanmasına olanak sağlayan MALDI-TOF sisteminin antibiyotik duyarlıık testlerinde de kullanılabileceğini gösteren çalışmalar bildirilmektedir. Çalışmamızda karbapenemaz üretiminin hızlı saptanmasına yönelik olarak ertapenemin karbapenemazlar tarafindan hidrolizinin VITEK-MS (bioMérieux, Fransa) sistemi tarafından tespit edilebilirliği değerlendirilmiștir. Çalışmamıza çeşitli klinik örneklerden izole edilen karbapenem dirençli $(n=86)$ ve duyarlı $(n=20)$ toplam 106 Klebsiella pneumoniae kökeni dahil edilmiștir. KPC, NDM, IMP, VIM ve OXA-48 genlerinin varlığını PCR ile tespit edilmiştir. Bakteri süspansiyonları 4 McFarland bulanıklığında hazırlanmış, $0.5 \mu \mathrm{g} / \mathrm{ml}$ lik ertapenem ile muamele edildikten sonra iki ve dört saat inkübe edilip analiz edilmek üzere VITEK-MS RUO (bioMérieux, Fransa) sistemine aktarılmıstır. Karbapenem dirençli 86 K.pneumoniae kökeninin bla ${ }_{\text {oxa-48 }}(n=39)$, bla $_{\text {NDM }}(n=37)$, bla $a_{M P}(n=8)$ ve bla $a_{\text {KPP }}(n=2)$ karbapenemaz genlerini tașıdığı tespit edilmiștir. Tüm antibiyotiklere duyarlı olan kökenlerde hiçbir karbapenemaz genine rastlanmamıştır. Ertapenemin tek başına sahip olduğu spektrumlar çalışma kökenlerinin ertapenem ile muamele edilip inkübe edilmesi sonucu elde edilen spektrumlar ile karşılaştırıldığında; iki saatlik inkübasyon sonrasında NDM, IMP ve KPC geni pozitif kökenlerin tamamında ertapenem hidrolizi gözlenirken, OXA-48 geni pozitif olan 14 kökende ertapenem hidrolizinin zayıf olduğu tespit edilmiștir. Dört saatlik inkübasyon sonrası OXA-48 geni pozitif olan kökenlerin sadece \% 64.1'inde ertapenem hidrolizi gözlemlenmiştir. iki ve dört saat inkübasyon sonrası karbapenemaz geni içermeyen kökenlerin hiçbirinde ertapenem hidrolizi gözlemlenmemistir. Rutin laboratuvarda mikroorganizmaların hızlı tespitinde önemli başarı sağlayan MALDI-TOF sistemlerinin antibiyotik duyarlılı testlerinde de benzer başarı göstermesi oldukça ümit vericidir. Ancak OXA-48 pozitif kökenlerin saptanmasını kolaylaştıracak farklı protokollerin geliştirilmesi gereklidir. MALDI-TOF sistemleri ile kısa sürede, düşük maliyetle karbapenemaz üretiminin tespit edilmesi özellikle salgınların çok daha kısa sürede kontrol altına alınmasında önemli katkı sağlayacaktır.

Anahtar kelimeler: ertapenem, karbapenemaz, Klebsiella pneumoniae, MALDI-TOF

\section{ABSTRACT}

In recent years, the increasing of infections caused by carbapenemase-producing Enterobacteriaceae (CPE) is an important public health problem in the worldwide. Some researchers have been reported studies showing that MALDI-TOF MS system can also be used in antibiotic susceptibility testing. The aim of this study was to evaluate the performance of VITEK-MS (bioMérieux, France) system based on ertapenem hidrolysis for the detection of carbapenemase activity. One hundered-six Klebsiella pneumoniae strains isolated from various clinical samples were tested in this study, which included 86 carbapenem resistant and 20 carbapenem susceptible isolates. The presence of KPC, NDM, IMP, VIM ve OXA-48 genes were detected by PCR. After the 4 McFarland bacterial suspensions was treated with $0.5 \mathrm{mg} / \mathrm{ml}$ of ertapenem, the suspension was incubated for $2 h$ and $4 h$, and transferred to VITEK-MS RUO (bioMérieux, France) system for analysis. Eighty-six carbapenem resistant K.pneumoniae strains had bla ${ }_{\text {axas }}(n=39)$, bla $(n=37)$, bla $(n=8)$ ve bla $(n=2)$ genes. No carbapenemase gene was found in the carbapenem susceptible K.pneumoniae strains. According to results of VITEK MS, ertapenem hydrolysis was observed in all of the NDM, IMP, and KPC after $2 \mathrm{~h}$ of incubation. Poor hydrolysis was observed in 14 OXA-48 positive strains within $2 \mathrm{~h}$. After $4 \mathrm{~h}$ of incubation strong ertapenem hydrolysis was observed in $64.1 \%$ of the OXA-48 positive strains. All non-carbapenemase producing strains were detected as negative. According to our study results, the detection of NDM, IMP and KPC using VITEK-MS seems to be a rapid, reliable and cost-effective method for routine laboratory. Since similar results were not observed in OXA-48, different protocols should be developed for the detection of these enzymes. The detection of carbapenemases by MALDI-TOF-MS systems in a short time will make a significant contribution especially in controlling the outbreaks.
Alındığı tarih: 12.03 .2019

Kabul tarihi: 22.04.2019

Yayın tarihi: 30.04 .2019

Gülşen Altnkanat Gelmez Marmara Üniversitesi Tıp Fakültesi Tıbbi Mikrobiyoloji Anabilim Dalı Başıbüyük Mah. Maltepe Başıbüyük Yolu Sok. No: 9/1, 34854 Maltepe İstanbul - Türkiye

- gulsenaltinkanat@yahoo.com ORCiD: 0000-0003-0274-628X

B. Can 0000-0002-1966-4243 U. Hasdemir 0000-0002-1606-0804 G. Söyletir 0000-0001-5695-731X Marmara Üniversitesi Tıp Fakültesi Tıbbi Mikrobiyoloji Anabilim Dalı Başıbüyük Mah. Maltepe Başıbüyük Yolu Sok. No: 9/1, 34854 Maltepe istanbul - Türkiye

*Çalışmamız 21-24 Nisan 2018'de Madrid'de düzenlenen 28th European Congress of Clinical Microbiology and Infectious Diseases (ECCMID) kongresinde sunulmuştur.

Keywords: carbapenemase, ertapenem, Klebsiella pneumoniae, MALDI-TOF 


\section{GiRiş}

Son yıllarda karbapenemaz üreten Enterobacteriaceae üyelerinin neden olduğu enfeksiyonların sıklığının tüm dünyada giderek artması oldukça endişe verici bir durumdur. Karbapenemazları kodlayan genler sıklıkla diğer antibiyotiklere ait direnç genlerini de barındıran konjugatif plazmid ve transpozonlarda taşınmaktadır. Enterobactericeae ailesinde en sık gözlemlenen karbapenemazlar sınıf A (KPC, GES), sınıf B (IMP, VIM, NDM) ve SInıf D (OXA48)'dir. Bu mobil genetik elementler türler arasında ve kişiden kişiye kolaylıkla yayılım gösterebilmektedir ${ }^{(8,17)}$. Bu nedenle antimikrobiyal yönetimin ve enfeksiyon kontrol önlemlerinin erken aşamada etkili olabilmesi için karbapenemaz üreten Enterobacteriaceae taşıyıcılarını veya enfeksiyonlarını rutin laboratuvarda tespit eden hızlı, güvenilir ve uygun maliyetli testlere ihtiyaç vardır. Karbapenemaz genlerinin moleküler yöntemlerle tespit edilmesi altın standart olmakla birlikte deneyimli personel ve spesifik ekipman gerektirmesi, pahalı olması nedeniyle rutin laboratuvarda uygulanması zordur. Öte yandan, ticari moleküler paneller yalnızca en yaygın beş karbapenemaz genini (KPC, NDM, OXA-48, IMP, VIM) tespit etmek üzere geliştirilmiştir. Ancak bu paneller yeni bulunan karbapenemaz genlerini tespit edemezler ${ }^{(19,20)}$. Son yıllarda, Enterobacteriaceae'deki karbapenemaz aktivitesinin saptanması için birçok fenotipik yöntem (Modifiye Hodge testi, karbapenem inaktivasyon yöntemi, immünokromatografik testler vb.) geliştirilmiştir. Farklı çalışmalarda, bu yöntemlerin duyarlılıklarının ve özgüllüğünün karbapenemaz türüne göre değiştiği bildirilmiştir. Bu testlerin bazıları uygulaması özen ve deneyim gerektiren ve uzun inkübasyon sürelerine ihtiyaç duyan testlerdir. Özellikle CARBA NP testi karbapenemlerin hidrolizi sonucu oluşan pH değişikliğine bağlı olarak karbapenemaz üretimini tespit edebilen hızlı bir test olmasına rağmen OXA-48 pozitif kökenlerin tespitinde yetersiz kalmaktadır. Bu nedenle, daha doğru, hassas ve kullanımı kolay fenotipik yöntemlere ihtiyaç vardır.

Matriks destekli lazer desorpsiyon/iyonizasyon uçuş zamanı kütle spektrometresi (MALDI-TOF MS) mikroorganizmaların tür ve cins düzeyinde hızlı tanımlanmasında kullanılmak üzere rutin mikrobiyoloji laboratuvarına giren önemli bir teknolojidir. Konvansiyonel yöntemlerle karşılaştırıldığında kısa sürede sonuç veren etkili bir sistemdir. Bu sistemler ile kısa sürede etkenin tür düzeyinde belirlenmesi uygun antimikrobiyal tedavinin başlanmasına \% 11-44 arasında katkı sağladığı yapılan çalışmalarda gösterilmiştir ${ }^{(10)}$. Son yıllarda araştırıcılar bu sistemlerin sadece mikroorganizmaların tanımlanmasında değil aynı zamanda antibiyotik duyarlılık testlerinde de kullanılabileceğini gösteren çalışmalar bildirmektedir. Özellikle beta laktamaz ve karbapenemazların antibiyotikleri hidroliz etmesi sonucu oluşan değişikliklerin MALDI-TOF MS aracığıyla saptanmasına yönelik çalışmalar tüm dünyada hız kazanmıştır ${ }^{(3,7,12-}$ 14,16,18,21,24).

Çalışmamızda VITEK-MS (bioMérieux SA, MarcyI'E'toile, Fransa) sistemi kullanılarak ertapenem hidrolizi aracığı ile karbapenemaz üretiminin hızlı saptanması amaçlanmıştır.

\section{GEREÇ VE YÖNTEM}

Bakterilerin Seçimi: Çalışmamızda, Marmara Üniversitesi Hastanesi Mikrobiyoloji Laboratuvarı'nda çeşitli klinik örneklerden etken olarak izole edilen ve otomatize sistem (VITEK Compact, bioMerieux SA, Marcy-l'E'toile, Fransa) ile ertapenem, meropenem ve imipenemden en az birine dirençli saptanan 86 Klebsiella pneumoniae kökeni dahil edilmiştir. Negatif kontrol grubu olarak tüm antibiyotiklere duyarlı saptanan 20 K.pneumoniae kökeni kullanılmıştır.

DNA ekstraksiyonu ve Karbapenemaz genlerinin amplifikasyonu: Çalışmaya dahil edilen K.pneumoniae kökenleri \% 5 koyun kanlı agara pasajlanıp bir gecelik inkübasyona bırakılmıştır. DNA izolasyonu için, inkübasyon sonrası üreyen kolonilerden 2-3 adet alınıp $250 \mu \mathrm{l}$ distile su içerinde bakteri süspansiyonu hazırlanarak $95^{\circ} \mathrm{C}$ 'de 10 dakika ısıtılmıştır. Bakteri süspansiyonu 5 dakika 13,000 x g'de santrifüj edildikten elde edilen süpernatan polimeraz zincir reaksiyonunda (PCR) kalıp DNA olarak kullanılmıştır. 
Tablo 1. PCR'da kullanılan primerler ve amplifikasyon koşulları.

\begin{tabular}{|c|c|c|c|c|}
\hline Primer & Dizi & Boyut(bp) & Amplifikasyon Koşulları & Referans \\
\hline OXA-48-R & 5'-TTG GTG GCA TCG ATT ATC GG-3' & \multirow{2}{*}{743} & \multirow{2}{*}{$94^{\circ} \mathrm{C} 5 \mathrm{dk}, 35$ siklus $\left(94^{\circ} \mathrm{C} 60 \mathrm{sn}, 56^{\circ} \mathrm{C} 45 \mathrm{sn}, 72^{\circ} \mathrm{C} 60 \mathrm{sn}\right), 72^{\circ} \mathrm{C} 7 \mathrm{dk}$} & \multirow{2}{*}{1} \\
\hline OXA-48-F & 5'-GAG CAC TTC TाT TGT GAT GGC-3' & & & \\
\hline NDM-R & 5'-GGG CAG TCG CTT CCA ACG GT-3' & \multirow{2}{*}{475} & \multirow{2}{*}{$95^{\circ} \mathrm{C} 5 \mathrm{dk}, 30$ siklus $\left(95^{\circ} \mathrm{C} 30 \mathrm{sn}, 60^{\circ} \mathrm{C} 40 \mathrm{sn}, 72^{\circ} \mathrm{C} 50 \mathrm{sn}\right), 72^{\circ} \mathrm{C} 6 \mathrm{dk}$} & \multirow{2}{*}{22} \\
\hline NDM-F & 5'-GTA GTG CTC AGT GTC GGC AT-3' & & & \\
\hline IMP-R & 5'- GAA GGY GTT TAT GTT CAT AC-3' & \multirow{2}{*}{587} & \multirow{2}{*}{$95^{\circ} \mathrm{C} 5 \mathrm{dk} 35$ siklus $\left(95^{\circ} \mathrm{C} 45 \mathrm{sn}, 60^{\circ} \mathrm{C} 45 \mathrm{sn}, 72^{\circ} \mathrm{C} 1 \mathrm{dk}\right), 72^{\circ} \mathrm{C} 8 d k$} & \multirow{2}{*}{23} \\
\hline IMP-F & 5'- GTA MGT TTC AAG AGT GAT GC-3' & & & \\
\hline VIM-R & 5'-GTT TGG TCG CAT ATC GCA AC-3' & \multirow{2}{*}{389} & \multirow{2}{*}{$95^{\circ} \mathrm{C} 5 \mathrm{dk}, 35$ siklus $\left(95^{\circ} \mathrm{C} 45 \mathrm{sn}, 60^{\circ} \mathrm{C} 45 \mathrm{sn}, 72^{\circ} \mathrm{C} 1 \mathrm{dk}\right), 72^{\circ} \mathrm{C} 8 \mathrm{dk}$} & \multirow{2}{*}{23} \\
\hline VIM-F & 5'- AAT GCG CAG CAC CAG GAT AG-3' & & & \\
\hline KPC-R & 5'-TGT CAC TGT ATC GCC GTC-3' & \multirow{2}{*}{880} & \multirow{2}{*}{$95^{\circ} \mathrm{C} 5 \mathrm{dk}, 35$ siklus $\left(95^{\circ} \mathrm{C} 45 \mathrm{sn}, 60^{\circ} \mathrm{C} 45 \mathrm{sn}, 72^{\circ} \mathrm{C} 1 \mathrm{dk}\right), 72^{\circ} \mathrm{C} 8 d k$} & \multirow{2}{*}{9} \\
\hline KPC-F & 5'-CTC AGT GCT CTA CAG AAA ACC-3' & & & \\
\hline
\end{tabular}

Ambler sınıflandırmasına göre en sık gözlemlenen karbapenemazlar olan sınıf A (KPC), sınıf B (NDM, IMP, VIM) ve sınıf D (OXA-48) beta-laktamazları kodlayan genler spesifik primerler ve amplifikasyon koşulları kullanılarak PCR ile tespit edilmiştir (Tablo $1)^{(1,9,22,23)}$. Her bir reaksiyon için 10X PCR tamponu, 2 $\mathrm{mM}$ dNTP, 3 pmol primer, $2.5 \mathrm{mM} \mathrm{MgCl}_{2}, 1 \mathrm{U}$ Taq DNA polimeraz ve $2 \mu \mathrm{l}$ of genomik DNA içeren 50 $\mu l^{\prime}$ lik PCR karışımı hazırlanıp amplifikasyon gerçekleştirilmiştir. Elde edilen PCR ürünleri, \% 1.5'luk agaroz jelde yürütülüp, etidyum bromid varlığında ultraviyole ışığı altında görüntülenmiştir.

Karbapenemaz üretiminin fenotipik tespiti: Karbapenemaz üretiminin fenotipik olarak saptanması MALDI-TOF MS sistemi kullanılmıştır. Çalışmada ertapenemin piyasadaki mevcut ticari formu olan Invanz IV/IM (1 gr) (Merck Sharp\&Dohme) etken madde olarak kullanılmıştır. Cihaz kalibrasyonu, LaunchPad version 2.9.3 software programında E.coli ATCC 8739 standart kökeni kullanılarak yapılmıştır. \% 5 koyun kanlı agarda 18-24 saat inkübe edilen kökenlerden \% 0.9'luk NaCl'de 4 McFarland bakteri süspansiyonu hazırlanıp 13,400 g'de santrifüj edilmiştir. Süpernatan atıldıktan sonra pellet üzerine 20 $\mu \mathrm{l}$ ertapenem $(0.5 \mu \mathrm{g} / \mathrm{ml})$ eklenip 2 saat ve 4 saat inkübe edilmiştir ${ }^{(15)}$. İnkübasyon sonrası tekrar santrifüj edilen örneklerin süpernatant kısmından $1 \mu$ l VITEK-MS (bioMérieux SA, Marcy-l'E'toile, Fransa) slaytına aktarıldıktan sonra üzerine $1 \mu \mathrm{l} \alpha$-siyano-4hidroksisinamik asit (CHCA) matriks solüsyonu eklenmiştir. Analiz işleminin gerçekleştirmek üzere üreticinin önerileri doğrultusunda VITEK-MS RUO (bioMérieux SA, Marcy-l'E'toile, Fransa) sistemine aktarılmıştır. sistemi kullanılarak ertapenemin tek başına spektrumları ile bakteri-ertapenem birlikteliklerinde elde edilen spektrumlar karşılaştırılmıştır. Ertapenemin tek başına sahip olduğu spektraların (388, 430, 476, 497 Da), test edilen kökenlerde gözlemlenmemesi karbapenemaz üretimi açısından pozitiflik olarak değerlendirilmiştir ${ }^{(5,6,14,15,25)}$. Çalışmamızda pozitif kontrol köken olarak; K.pneumoniae ATCC BAA-1705(KPC-2 pozitif köken), K.pneumoniae IMP-1 pozitif köken, P.aeruginosa VIM-4 pozitif köken, K.pneumoniae 05-506 (NDM-1 pozitif köken), K.pneumoniae 4936 (OXA-48 pozitif köken), negatif kontrol köken olarak da E.coli ATCC 25922 ve K. pneumoniae ATCC BAA-1706 kullanılmıştır ${ }^{(1,2,26)}$.

\section{BULGULAR}

Çalışmaya dahil edilen 86 K.pneumoniae kökeninin bla ${ }_{O X A-48}(\mathrm{n}=39)$, bla $_{N D M}(\mathrm{n}=37)$, bla $_{I M P}(\mathrm{n}=8)$ ve bla $_{K P C}(\mathrm{n}=2)$ karbapenemaz genlerini taşıdığı moleküler olarak tespit edilmiştir. Kökenlerin hiçbirinde bla $_{\text {VIM }}$ geni tespit edilmemiştir. Negatif kontrol grubunda ise test edilen karbapenemaz genlerinin hiçbiri saptanmamıştır.

Ertapenemin tek başına sahip olduğu spektrumlar (388, 430, 476, 497Da) çalışma kökenleriertapenem birlikteliklerinde saptanan spektrumlar ile karşılaştırıldığında; 2 saatlik inkübasyon sonrasında bla ${ }_{N D M}$ bla $a_{I M P}$ ve bla ${ }_{K P C}$ geni pozitif kökenlerin tamamında ertapenem hidrolizi gözlenirken, bla ${ }_{\text {OXA-48 }}$ geni pozitif olan kökenlerde ertapenem hidrolizinin zayıf olduğu tespit edilmiştir. Dört saatlik inkübasyon sonrası bla $a_{O X A-48}$ geni pozitif olan kökenlerin sadece 25 'inde (\% 64.1) ertapenem hidrolizi gözlemlenmiştir. İki ve 4 saat inkübasyon sonrası karbapenemaz 
geni içermeyen kökenlerin hiçbirinde ertapenem hidrolizi gözlemlenmemiştir. Testin özgüllüğü 2. ve 4. saatte \% 100 iken, duyarlığı sırasıyla \% 70.9 ve \% 83.7 olarak tespit edilmiştir (Tablo 2).

Tablo 2. Karbapenemaz üretiminin VITEK-MS ile analiz sonuçları.

\begin{tabular}{ccc}
\hline VITEK MS ile karbapenem hidrolizi & $\begin{array}{c}\text { Karbapenemaz } \\
\text { Pozitif }(\mathbf{n})\end{array}$ & $\begin{array}{c}\text { Karbapenemaz } \\
\text { Negatif }(\mathbf{n})\end{array}$ \\
\hline \hline Karbapenem hidrolizi pozitif & & \\
2. saat & 61 & 20 \\
4. saat & 72 & 20 \\
Karbapenem hidrolizi negatif & & \\
2. saat & 25 & 20 \\
4. saat & 14 & 20 \\
\hline \hline
\end{tabular}

\section{TARTIŞMA}

Günümüzde antibiyotik direnci halk sağlığını tehdit eden çok önemli bir sorundur. Son yıllarda tüm dünyada karbapenem direncinde gelinen nokta endişe verici düzeylerdedir. Karbapenem direncine neden olan en önemli mekanizma karbapenemaz üretimidir. Şimdiye kadar 100'den fazla karbapenemaz enzimi tanımlanmıştır ${ }^{(4)}$. Karbapenemaz üreten Enterobactericeae üyelerinin neden olduğu enfeksiyonların sıklığının artması ve yeni geliştirilen antimikrobiyallerin sayısının azalması nedeniyle bu dirençli mikroorganizmaların yayılımının önlenmesinde yeni stratejilere ihtiyaç vardır. Bu hedefe ulaşmanın önemli bir basamağı da direnç mekanizmasının en erken sürede belirlenmesidir. Bu amaçla rutin mikrobiyoloji laboratuvarında direnç mekanizmaların saptanmasına yönelik hızlı tanı testlerinin geliştirilmesine ihtiyaç doğmuştur.

Karbapenem direncinin saptanması rutin laboratuvarlarda antibiyotik duyarlılık testleri, fenotipik ve genotipik yöntemler kullanılarak yapılmaktadır. Bu amaçla rutin laboratuvarda kullanılmak üzere birçok fenotipik yöntem (Modifiye Hodge, karbapenem inaktivasyon metodu, CARBA-NP vs.) geliştirilmiştir. Her ne kadar bu yöntemlerin bazıları antibiyotik duyarlılık rehberleri (EUCAST, CLSI) tarafından önerilse de yapılan çalışmalarda bu testlerin farklı özgüllük ve duyarlılıklara sahip olduğu belirlenmiştir. Şu ana kadar geliştirilen fenotipik yöntemler tüm karbape- nemaz tiplerini saptayabilme yeteneğine sahip değildir. Özellikle OXA-48 pozitif kökenlerin bu fenotipik yöntemlerle tanımlanmasında sıkıntılar vardır ${ }^{(16,24)}$. Ayrıca bu yöntemlerin birçoğu uzun inkübasyon sürelerine ihtiyaç duymaktadır. Bu nedenle gerek enfeksiyon kontrol önlemlerinin yapılması gerekse uygun tedavi protokollerinin oluşturulabilmesi gecikmektedir. Genotipik testlerde ise aynı gün içerisinde sonuç alınabilmesine rağmen daha pahalı olması ve deneyimli personel ve ekipman ihtiyacı nedeniyle rutin laboratuvarlarda kullanımları zordur.

Konvansiyonel tanımlama yöntemleri ile kıyaslandığında çok sayıda mikroorganizmanın cins ve tür düzeyinde doğru ve kısa sürede tanımlanmasına olanak sağlayan MALDI-TOF MS sistemlerinin rutin mikrobiyoloji laboratuvarlarında kullanıma girmesi önemli bir devrim yaratmıştır. MALDI-TOF sistemleri son yıllarda önemli direnç mekanizmalarına sahip mikroorganizmaların ayırt edilmesinde de kullanımaya başlamıştır. Direncin bu yöntemle ortaya konabilmesi hücre duvar yapıları ve proteomdaki değişiklerin saptanmasına ya da enzimlerin (beta laktamaz, karbapenemaz vb.) antimikrobiyaller üzerinde yaptığı değişikliklerin saptanmasına dayanmaktadır. Bu sayede rutin laboratuvarda çok kısa sürede mikroorganizmanın herhangi bir enzimatik dirence sahip olup olmadığı tespit edilebilmektedir ${ }^{(3,11,12,13)}$.

Karbapenemaz aktivitesinin MALDI-TOF MS ile tespiti için her ne kadar standart bir protokol bulunmasa da farklı yöntemler kullanılarak birçok çalışmada yapılmıştır. Bu çalışmalarda testlerin duyarlılıkları \% 77-100, özgüllükleri \% 94-100 arasında değişmektedir. Yalancı negatif sonuçlar çoğunlukla OXA-48 pozitif kökenlerde tespit edilmiştir( ${ }^{(3,7,14,12,13,16,18,21,24)}$. Çalışmamızda ise KPC, NDM ve IMP tipi karbapenemazların VITEK MS ile tespiti 2 saat gibi kısa bir sürede sağlanmıştır. Ayrıca negatif kontrol grubunda yalancı pozitiflik saptanmamıştır. Bu karbapenemaz tipleri için testin duyarlık ve özgüllüğü \% 100'dür. Ancak inkübasyon süresi 4 saate uzatılmasına rağmen OXA-48 tipi karbapenemazların sadece \% 64.1'i tespit edilebilmiştir. Bu nedenle testin duyarlılığı \% 83.7 olarak tespit edilmiştir. Literatürdeki diğer çalışmalara benzer şekilde kullandığımız protokol ile 
OXA-48'lerin yaklaşık $1 / 3$ tespit edilememiştir. IIlk olarak Türkiye'de tanımlanan OXA-48 enzimi daha sonra Orta Doğu, Hindistan, Kuzey Afrika ve birçok Avrupa ülkesinde bildirilmeye başlanmıştır ${ }^{(1,18)}$. Ülkemizde en sık karşılaşılan karbapenemaz olması nedeniyle oldukça önemlidir. Bu nedenle ülkemiz gibi OXA-48'in yaygın görüldüğü ülkelerde bu enzimin kısa sürede tespiti enfeksiyon kontrol önlemlerinin alınabilmesi için oldukça önemlidir. MALDI-TOF ile OXA-48'lerin tespit edilememesi diğer fenotipik testlerde olduğu gibi düşük hidroliz aktivitesine bağlanmaktadır. Bunun yanı sıra ülkemizde ikinci sıklıkla karşılaşılan karbapenemaz NDM'dir ve bu enzimlerin tespiti de oldukça önemlidir. Çalışmamızda kullanılan yöntem ile NDM pozitif kökenlerin kısa sürede tespit edilmesi bu enzimlere sahip mikroorganizmaların yayılımının önlenmesinde ve antimikrobiyal yönetimine büyük katkı sağlayacaktır.

MALDI-TOF MS'in en önemli avantajı üreme gözlemlenen klinik örneklerden identifikasyon sonrası çok kısa sürede karbapenemaz üretimi hakkında bilgi sahibi olunabilir. Aynı zamanda tek bir slayt üzerinde çok sayıda kökenin aynı anda çalışılabilmesi mümkündür. Bu kadar kısa sürede sonuç alınabilmesi bu mikroorganizmaların neden olduğu enfeksiyonların yönetiminde ve yayılımlarının önlenmesinde kritik önem taşımaktadır. Özellikle salgın şüphesi olan durumlarda hızlı sonuç elde edebilmek için oldukça avantajıdır. Uygulanması oldukça kolaydır ve değerlendirmenin bilgisayar aracılı olması sonuçların yorumlanmasındaki hataları minimize etmektedir. Cihazın temini yapıldıktan sonra test maliyeti oldukça ucuzdur. Eş zamanlı olarak birden fazla enzimatik kaynaklı direnç profili test edilebilir. Bu yöntemin en önemli dezavantajı ise diğer karbapenem direnç mekanizmalarını saptayamamaktadır. OXA-48 pozitif kökenlerin tespitindeki zorluklar mevcut yöntemler ile hala zor gibi gözükmektedir. OXA-48 üreten kökenlerin daha iyi tespit edilebilmesi için yeni protokoller geliştirilmesine intiyaç vardır.

Etik Kurul Onayı: Marmara Üniversitesi Tıp Fakültesi Klinik Araştırmalar Etik Kurulu'nun onayı alınmıştır. (01.03.2016/270)
Çıkar Çatışması: Yazarlar tarafından herhangi bir çıkar çatışması bildirilmemiştir.

Ethics Committee Approval: Approval was obtained from Marmara University Faculty of Medicine Clinical Research Ethics Committee. (01.03.2016 / 270)

Conflict of Interest: No conflict of interest was declared by the authors.

\section{KAYNAKLAR}

1. Aktaş Z, Kayacan CB, Schneider I, et al. Carbapenemhydrolyzing oxacillinase, OXA-48, persists in Klebsiella pneumoniae in Istanbul, Turkey. Chemotherapy. 2008;54(2):101-6. doi: 10.1159/000118661. Epub 2008 Feb 25. PubMed PMID: 18303258. https://doi.org/10.1159/000118661

2. Aktaş Z, Kayacan CB. Investigation of metallo-betalactamase producing strains of Pseudomonas aeruginosa and Acinetobacter baumannii by E-test, disk synergy and PCR. Scand J Infect Dis. 2008;40(4):320-5. https://doi.org/10.1080/00365540701704698

3. Burckhardt I, Zimmermann S. Using matrix-assisted laser desorption ionization-time of flight mass spectrometry to detect carbapenem resistance within 1 to 2.5 hours. J Clin Microbiol. 2011;49(9):3321-4. https://doi.org/10.1128/JCM.00287-11

4. Bush K, Jacoby GA. Updated functional classification of beta-lactamases. Antimicrob Agents Chemother. 2010;54(3):969-76. doi: 10.1128/AAC.01009-09. Epub 2009 Dec 7. Review. PubMed PMID: 19995920 https://doi.org/10.1128/AAC.01009-09

4. Bush K, Jacoby GA. Updated functional classification of beta-lactamases. Antimicrob Agents Chemother. 2010;54(3):969-76. doi: 10.1128/AAC.01009-09. Epub 2009 Dec 7. Review. PubMed PMID: 19995920; PubMed Central PMCID: PMC2825993. https://doi.org/10.1128/AAC.01009-09

5. Carvalhaes CG, Cayô R, Visconde MF, et al. Detection of carbapenemase activity directly from blood culture vials using MALDI-TOF MS: a quick answer for the right decision. J Antimicrob Chemother. 2014;69(8):2132-6. https://doi.org/10.1093/jac/dku094

6. Carvalhaes CG, da Silva AC, Streling AP, et al. Detection of c carbapenemase activity using VITEK 
MS: interplay of carbapenemase type and period of incubation. J Med Microbiol. 2015;64(8):946-7.

https://doi.org/10.1099/jmm.0.000102

7. Chong PM, McCorrister SJ, Unger MS, et al. MALDITOF MS detection of carbapenemase activity in clinical isolates of Enterobacteriaceae spp., Pseudomonas aeruginosa, and Acinetobacter baumannii compared against the Carba-NP assay. J Microbiol Methods. 2015;111:21-3.

https://doi.org/10.1016/j.mimet.2015.01.024

8. Cohen Stuart J, Leverstein-Van Hall MA; Dutch working party on the detection of highly resistant microorganisms. Guideline for phenotypic screening and confirmation of carbapenemases in Enterobacteriaceae. Int J Antimicrob Agents. 2010;36(3):205-10. https://doi.org/10.1016/j.ijantimicag.2010.05.014

9. Cole JM, Schuetz AN, Hill CE, et al. Development and evaluation of a real-time PCR assay for detection of Klebsiella pneumoniae carbapenemase genes. J Clin Microbiol. 2009;47(2):322-6.

https://doi.org/10.1128/JCM.01550-08

10. Hammoudi D, Moubareck CA, Sarkis DK. How to detect carbapenemase producers? A literature review of phenotypic and molecular methods. J Microbiol Methods. 2014;107:106-18.

https://doi.org/10.1016/j.mimet.2014.09.009

11. Hrabák J, Chudáčková E, Papagiannitsis CC. Detection of carbapenemases in Enterobacteriaceae: a challenge for diagnostic microbiological laboratories. Clin Microbiol Infect. 2014;20(9):839-53. https://doi.org/10.1111/1469-0691.12678

12. Hrabak J, Walkova R, Studentova V, et al. Carbapenemase activity detection by matrix-assisted laser desorption ionization-time of flight mass spectrometry. J Clin Microbiol. 2011;49(9):3222-7. https://doi.org/10.1128/JCM.00984-11

13. Hrabák J, Chudácková E, Walková R. Matrix-assisted laser desorption ionization-time of flight (MALDITOF) mass spectrometry for detection of antibiotic resistance mechanisms: from research to routine diagnosis. Clin Microbiol Rev. 2013;26(1):103-14. https://doi.org/10.1128/CMR.00058-12

14. Hoyos-Mallecot Y, Cabrera-Alvargonzalez JJ, MirandaCasas C, et al. MALDI-TOF MS, a useful instrument for differentiating metallo- $\beta$-lactamases in Enterobacteriaceae and Pseudomonas spp. Lett Appl Microbiol. 2014;58(4):325-9.

https://doi.org/10.1111/lam.12203
15. Johansson A, Ekelöf J, Giske CG, et al. The detection and verification of carbapenemases using ertapenem and matrix assisted laser desorption lonizationtime of flight. BMC Microbiol. 2014;14:89. https://doi.org/10.1186/1471-2180-14-89

16. Knox J, Jadhav S, Sevior D, et al. Phenotypic detection of carbapenemase-producing Enterobacteriaceae by use of matrix-assisted laser desorption ionizationtime of flight mass spectrometry and the Carba NP test. J Clin Microbiol. 2014;52(11):4075-7. https://doi.org/10.1128/JCM.02121-14

17. Lee CR, Lee JH, Park KS, et al. Global dissemination of carbapenemase-producing Klebsiella pneumoniae: Epidemiology, genetic context, treatment options, and detection methods. Front Microbiol. 2016;7:130.

https://doi.org/10.3389/fmicb.2016.00895

18. Mirande C, Canard I, Croix Blanche SB, et al. Rapid detection of carbapenemase activity: benefits and weaknesses of MALDI-TOF MS. Eur J Microbiol Infect Dis. 2015;34(11):2225-34. https://doi.org/10.1007/s10096-015-2473-z

19. Morency-Potvin P, Schwartz DN, Weinstein RA. Antimicrobial stewardship: How the microbiology laboratory can right the ship. Clin Microbiol Rev. 2016;30(1):381-407. https://doi.org/10.1128/CMR.00066-16

20. Osei Sekyere J, Govinden U, Essack SY. Review of established and innovative detection methods for carbapenemase-producing Gram-negative bacteria. J Appl Microbiol. 2015;119(5):1219-33 https://doi.org/10.1111/jam.12918

21. Ovia-o M, Barba MJ, Fernández B, et al. Rapid detection of OXA-48-Producing Enterobacteriaceae by matrix-assisted laser desorption ionization-time of flight mass spectrometry. J Clin Microbiol. 2016;54(3):754-9. https://doi.org/10.1128/JCM.02496-15

22. Perry JD, Naqvi SH, Mirza IA, et al. Prevalence of faecal carriage of Enterobacteriaceae with NDM-1 carbapenemase at military hospitals in Pakistan, and evaluation of two chromogenic media. J Antimicrob Chemother. 2011;66(10):2288-94. https://doi.org/10.1093/jac/dkr299

23. Pitout JD, Gregson DB, Poirel L, et al. Detection of Pseudomonas aeruginosa producing metallo-betalactamases in a large centralized laboratory. J Clin Microbiol. 2005;43(7):3129-35. https://doi.org/10.1128/JCM.43.7.3129-3135.2005 
24. Tijet N, Boyd D, Patel SN, et al. Evaluation of the Carba NP test for rapid detection of carbapenemaseproducing Enterobacteriaceae and Pseudomonas aeruginosa. Antimicrob Agents Chemother. 2013;57(9):4578-580.

https://doi.org/10.1128/AAC.00878-13

25. Vogne C, Prod'hom G, Jaton K, et al. A simple, robust and rapid approach to detect carbapenemases in Gram-negative isolates by MALDI-TOF mass spectrometry: validation with triple quadripole tandem mass spectrometry, microarray and PCR. Clin Microbiol Infect. 2014;20(12): 01106-12.

https://doi.org/10.1111/1469-0691.12715

26. Yong D, Toleman MA, Giske CG, et al. Characterization of a new metallo-beta-lactamase gene, bla(NDM-1), and a novel erythromycin esterase gene carried on a unique genetic structure in Klebsiella pneumoniae sequence type 14 from India. Antimicrob Agents Chemother. 2009;53(12):5046-54.

https://doi.org/10.1128/AAC.00774-09 